\title{
PENGARUH MODEL PEMBELAJARAN KOOPERATIF TIPE SFAE BERBANTUAN KOMIK EDUKATIF TERHADAP PEMAHAMAN KONSEP FISIKA SISWA KELAS X SMA NEGERI 1 PALU
}

\author{
Nursyamsi, Muslimin, dan Amiruddin Hatibe \\ Jurusan Pendidikan MIPA \\ Fakultas Keguruan dan Ilmu Pendidikan Universitas Tadulako Palu
}

\begin{abstract}
Abstrak
Penelitian ini bertujuan untuk mengetahui ada tidaknya pengaruh model pembelajaran kooperatif tipe Student Facilitator and Explaining (SFAE) berbantuan komik edukatif terhadap pemahaman konsep fisika siswa kelas X SMA Negeri 1 Palu. Jenis penelitian ini adalah eksperimen kuasi yang menggunakan desain penelitian the equivalent pretest-postest design. Penelitian ini menggunakan sampel pada kelas $X$ IPA 2 sebagai kelas eksperimen dan kelas X IPA 1 sebagai kelas kontrol, dengan sampel pada masingmasing kelas berjumlah 32 dan 30 siswa. Instrumen penelitian berupa tes pemahaman konsep berbentuk tes pilihan ganda beralasan berjumlah 20 soal. Berdasarkan tes pemahaman konsep yang diperoleh menunjukkan bahwa nilai posttest lebih tinggi daripada nilai pretest. Adapun skor tertinggi posttest yaitu 37 dan skor tertinggi pretest yaitu 31. Uji peningkatan hasil tes diperoleh nilai rata-rata $\mathrm{N}$-gain yaitu $55,28 \%$ dengan kriteria sedang. Hasil perhitungan dari uji hipotesis (uji-t) diperoleh thitung sebesar 4,04 dan $t_{\text {tabel }}$ pada taraf nyata $\alpha=0,05$ dan $\mathrm{dk}=60$ yaitu 1,67 . Hal ini berarti bahwa nilai $t_{\text {hitung }}$ berada diluar daerah penerimaan $H_{0}$. Dengan demikian, terdapat pengaruh model pembelajaran kooperatif tipe SFAE berbantuan komik edukatif terhadap pemahaman konsep fisika siswa kelas X SMA Negeri 1 Palu.
\end{abstract}

Kata Kunci : model SFAE,komik edukatif,pemahaman konsep fisika

\section{PENDAHULUAN}

Pendidikan merupakan kebutuhan yang sangat penting bagi manusia. Seseorang yang memiliki pendidikan yang baik akan mampu bersaing dan menghadapi setiap perubahan menuju arah yang lebih baik. Pendidikan berkenaan dengan upaya pembinaan manusia, maka keberhasilan pendidikan sangat tergantung pada unsur manusianya. Dalam hal ini, diperlukan pembelajaran dalam proses pendidikan karena disitulah seorang guru dapat mengetahui tingkat kemampuan siswa terhadap materi yang disampaikan. Pembelajaran juga harus disesuaikan dengan kebutuhan belajar untuk mencapai tujuan pendidikan.

Permasalahan yang sering dihadapi dalam dunia pendidikan salah satunya adalah rendahnya hasil belajar siswa. Hal ini merupakan wujud dari pemahaman siswa yang kurang terhadap materi yang diajarkan. Model pembelajaran yang dapat digunakan sebagai salah satu alternatif untuk meningkatkan pemahaman konsep siswa adalah model pembelajaran student facilitator and explaining (SFAE). Model pembelajaran SFAE merupakan salah satu model kooperatif dimana siswa sebagai fasilitator dan di ajak berpikir secara kreatif sehingga menghasilkan pertukaran informasi yang lebih mendalam dan lebih menarik [1].

Model pembelajaran sebagai alat motivasi ekstrinsik dalam kegiatan belajar mengajar hendaknya dipahami benar oleh guru. Penentuan model pembelajaran yang digunakan oleh guru sangat menunjang keberhasilan suatu proses pembelajaran karena dapat membangun suasana belajar yang menarik perhatian siswa dan menyenangkan bagi siswa, sehingga siswa dapat memusatkan perhatiannya secara penuh pada belajarnya [2].

Penelitian serupa pernah dilakukan oleh Mawarsih [3] yang menyatakan bahwa rata-rata hasil belajar pada kelompok yang menggunakan model pembelajaran SFAE memiliki rata-rata yang lebih tinggi daripada kelompok yang tidak menggunakan model SFAE.

Nirsam [4] menyatakan dalam penelitiannya menggunakan model pembelajaran kooperatif tipe SFAE terjadi peningkatan hasil belajar siswa dari siklus I ke siklus II dimana siklus I berada pada kategori kurang dan cukup, sedangkan pada siklus II berada pada kategori baik dan sangat baik dan hasil wawancara menunjukkan bahwa siswa senang dengan model pembelajaran yang diterapkan.

Putut, Hikmawati, dan Satutik [5] dalam penelitiannya menyatakan bahwa terdapat pengaruh model pembelajaran SFAE dengan pendekatan saintifik terhadap hasil belajar fisika siswa kelas $X$ MIPA SMA Negeri 1 Tanjung. Dimana hasil belajar siswa kelas X MIPA 2 yang mengikuti model pembelajaran SFAE dengan pendekatan saintifik lebih meningkat dibandingkan siswa kelas $X$ MIPA 1 yang mengikuti pembelajaran konvensional.

Peneliti memberikan hal yang baru dari penelitian yang pernah ada sebelumnya, dimana 
pada penelitian ini model pembelajaran kooperatif tipe SFAE dibuat berbeda yaitu dengan berbantuan komik edukatif. Dengan perpaduan model SFAE menggunakan komik edukatif maka siswa diajak untuk menjelaskan kepada siswa lainnya dan dapat mengeluarkan ide-ide yang ada dipikirannya dengan menggunakan komik edukatif yang dapat lebih memperjelas materi, menarik minat siswa untuk belajar sehingga siswa dapat lebih memahami materi tersebut.

Berdasarkan latar belakang yang telah dikemukakan, maka rumusan masalah pada penelitian ini adalah "Apakah terjadi peningkatan hasil tes pemahaman konsep pada siswa kelas eksperimen dan kelas kontrol sehingga terdapat pengaruh model pembelajaran kooperatif tipe student facilitator and explaining (SFAE) berbantuan komik edukatif terhadap pemahaman konsep fisika kelas X di SMA Negeri 1 Palu". Adapun hipotesis penelitian adalah $\mathrm{H}_{0}$ yaitu tidak terdapat pengaruh model pembelajaran kooperatif tipe SFAE berbantuan komik edukatif terhadap pemahaman konsep fisika siswa kelas X SMA Negeri1 Palu, dan $\mathrm{H}_{1}$ yaitu terdapat pengaruh model pembelajaran kooperatif tipe SFAE berbantuan komik edukatif terhadap pemahaman konsep fisika siswa kelas X SMA Negeri1 Palu. Adapun tujuan penelitian ini yaitu untuk mengetahui peningkatan hasil tes pemahaman konsep pada siswa kelas eksperimen dan kelas kontrol sehingga dapat diketahui ada tidaknya pengaruh model pembelajaran kooperatif tipe SFAE (Student Facilitator and Explaining) berbantuan komik edukatif terhadap pemahaman konsep fisika siswa kelas X SMA Negeri 1 Palu.

\section{METODE PENELITIAN}

Jenis penelitian yang digunakan adalah jenis penelitian kuantitatif dengan menggunakan metode eksperimen kuasi (quasi-experiment).

Desain penelitian menggunakan the equivalen pretest-postest design. Rancangan ini melibatkan dua kelompok, yaitu kelompok eksperimen dan kelompok kontrol. Sebelum diberikan perlakuan pada kedua kelas diberikan pretest. Selanjutnya kelompok eksperimen diberikan perlakuan khusus yaitu model pembelajaran kooperatif tipe SFAE berbantuan komik edukatif, sedangkan kelompok kontrol diberikan pembelajaran menggunakan pembelajaran konvensional. Setelah perlakuan, kedua kelas diberikan posttest.

TABEL 1 (THE EQUIVALEN PRETEST-POSTEST DESIGN)

\begin{tabular}{cccc}
\hline Kelompok & Tes Awal & Perlakuan $(\mathrm{X})$ & Tes Akhir \\
\hline A & $\mathrm{O}_{1}$ & $X_{1}$ & $\mathrm{O}_{2}$ \\
\hline B & $\mathrm{O}_{1}$ & $X_{2}$ & $\mathrm{O}_{2}$ \\
\hline
\end{tabular}

Keterangan:

$\begin{array}{ll}\mathrm{A} & : \text { Kelompok eksperimen } \\ \mathrm{B} & : \text { Kelompok kontrol } \\ \mathrm{X}_{1} & : \text { Model pembelajaran kooperatif tipe SFAE } \\ & \text { berbantuan komik edukatif } \\ \mathrm{X}_{2} & : \text { Model pembelajaran konvensional } \\ \mathrm{O}_{1} & : \text { Tes awal (pretest) } \\ \mathrm{O}_{2} & : \text { Tes akhir (posttest) }\end{array}$

Penelitian ini dilaksanakan di kelas X SMA Negeri 1 Palu semester genap pada tahun ajaran 2018/2019. Populasi penelitian ini keseluruhan siswa kelas X SMA Negeri 1 Palu. Sampel penelitian diambil dengan teknik purposive sampling. Jumlah sampel pada kelas X IPA 2 sebagai kelas eksperimen dan kelas $X$ IPA 1 sebagai kelas kontrol, masing-masing kelas berjumlah 32 dan 30 siswa.

Instrumen yang digunakan dalam penelitian ini adalah tes pemahaman konsep berupa tes pilihan ganda beralasan berjumlah 20 soal. Tes disusun berdasarkan indikator yang disesuaikan dengan kurikulum. Skor yang digunakan pada pilihan ganda beralasan untuk jawaban dan alasan yang benar bernilai (2), untuk jawaban benar namun alasan salah atau sebaliknya bernilai satu (1), dan untuk jawaban dan alasan yang salah bernilai nol
(0). Selanjutnya data yang diperoleh dari penelitian ini diolah dengan menggunakan uji statistik berupa uji normalitas, uji homogenitas, uji $N-$ Gain dan uji hipotesis [6].

\section{HASIL DAN PEMBAHASAN}

\section{Hasil Penelitian}

1. Hasil Uji Normalitas (Posttest)

Uji normalitas data digunakan untuk mengetahui apakah populasi data berdistribusi normal atau tidak. Data yang akan diujikan adalah data hasil posttest pada kelas eksperimen dan kelas kontrol. Pengujian normalitas data posttest pada penelitian ini menggunakan uji Chi-kuadrat dengan kriteria penerimaan $\chi_{\text {hitung }}^{2}<\chi_{\text {tabel }}^{2}$, taraf signifikan $a=0,05$, dan $\mathrm{dk}=\left(\mathrm{n}_{1}+\mathrm{n}_{2}-2\right)$. 
TABEL 2 HASIL UJI NORMALITAS DISTRIBUSI TES AKHIR PADA KELAS EKSPERIMEN DAN KELAS KONTROL

\begin{tabular}{ccccc}
\hline No. & Kelas & Nilai $\chi_{\text {thiturs }}^{z}$ & Nilai $x_{t=\mathrm{Bs}}^{z}$ & Keputusan \\
\hline 1. & Eksperimen & 4,05 & 7,81 & $\begin{array}{c}\text { Terdistribusi } \\
\text { Normal }\end{array}$ \\
\hline 2. & Kontrol & 2,13 & 7,81 & $\begin{array}{c}\text { Terdistribusi } \\
\text { Normal }\end{array}$ \\
\hline
\end{tabular}

Berdasarkan Tabel 2 terlihat bahwa nilai $\chi_{\text {hitung }}^{2}$ kelas eksperimen maupun kelas kontrol lebih kecil dari pada nilai $\chi_{\text {tabel }}^{2}$. Artinya, hasil ini menunjukkan bahwa data posttest kelas eksperimen maupun kelas kontrol terdistribusi normal.
2. Hasil Uji Homogenitas (Posttest)

Uji homogenitas pada penelitian ini menggunakan uji statistik $\mathrm{F}$ dengan taraf signifikan $=0,05$. Uji Homogenitas dilakukan untuk melihat apakah data berasal dari varians yang sama atau tidak.

TABEL 3 HASIL UJI HOMOGENITAS POSTTEST KELAS EKSPERIMEN DAN KELAS KONTROL

\begin{tabular}{|c|c|c|c|c|c|}
\hline No. & Kelas & Nilai Varians & $\begin{array}{l}\text { Varians } \\
\text { Hitung }\end{array}$ & $\begin{array}{c}\text { Nilai } F \text { tabel } \\
(a=0,05)\end{array}$ & Keputusan \\
\hline 1 & $\begin{array}{r}\text { Kelas X IPA } 2 \\
\text { (Eksperimen) }\end{array}$ & 182,08 & \multirow{2}{*}{1,30} & \multirow[b]{2}{*}{1,67} & \multirow{2}{*}{$\begin{array}{l}\text { Kedua data } \\
\text { homogen }\end{array}$} \\
\hline 2 & $\begin{array}{c}\text { Kelas X IPA } 1 \\
\text { (Kontrol) }\end{array}$ & 140,49 & & & \\
\hline
\end{tabular}

Berdasarkan hasil uji homogenitas pada Tabel 3 dengan taraf signifikan $(a=0,05)$, dari data tersebut terlihat bahwa $\mathrm{F}_{\text {hitung }}$ lebih kecil dari $\mathrm{F}_{\text {tabel }}$, maka berdasarkan kriteria pengambilan keputusan dapat disimpulkan bahwa varians antara kelas eksperimen dan kelas kontrol adalah sama atau homogen.

3. Hasil Tes Pemahaman Konsep

TABEL 4 DESKRIPSI HASIL TES PEMAHAMAN KONSEP PADA KELAS EKSPERIMEN DAN KELAS KONTROL

\begin{tabular}{|l|c|c|c|c|}
\hline \multirow{2}{*}{ Uraian } & \multicolumn{2}{|c|}{ Tes Awal (Pretest) } & \multicolumn{2}{c|}{ Tes Akhir (Posttest) } \\
\cline { 2 - 5 } & $\begin{array}{c}\text { Kelas Eksperimen } \\
\text { (X IPA 2) }\end{array}$ & $\begin{array}{c}\text { Kelas Kontrol (X } \\
\text { IPA 1) }\end{array}$ & $\begin{array}{c}\text { Kelas Eksperimen } \\
\text { (X IPA 2) }\end{array}$ & $\begin{array}{c}\text { Kelas Kontrol (X } \\
\text { IPA 1) }\end{array}$ \\
\hline Sampel & 32 & 30 & 32 & 30 \\
\hline Skor Terendah & 5 & 6 & 23 & 16 \\
\hline Skor Tertinggi & 26 & 27 & 37 & 32 \\
\hline Skor Rata-rata & 39,06 & 41,80 & 73,59 & 60,73 \\
\hline Standar Deviasi & 10,71 & 14,52 & 9,34 & 10,02 \\
\hline
\end{tabular}

4. Uji N-Gain

Uji $N$-Gain pada penelitian ini digunakan untuk mengetahui apakah terjadi peningkatan pemahaman konsep pada siswa kelas eksperimen.

TABEL 5 HASIL UJI N-GAIN TES AKHIR PADA KELAS EKSPERIMEN

\begin{tabular}{ccccc}
\hline No. & Uraian & Pretest & Posttest & N-Gain \\
\hline 1. & Sampel & 32 & 32 & 32 \\
\hline 2. & Nilai rata-rata & 16,25 & 29,34 & 55,28 \\
\hline 3. & Standar Deviasi & 4,03 & 5,42 & 7,44 \\
\hline
\end{tabular}

Berdasarkan hasil uji $N$-gain pada tabel diperoleh nilai rata-rata $\mathrm{N}$-gain pada kriteria sedang, dimana $30 \leq \mathrm{g}<70$. $\mathrm{H}$ al ini berarti terjadi peningkatan hasil belajar fisika yang baik pada siswa kelas eksperimen yang mengikuti model pembelajaran yang diterapkan.
5. Uji Hipotesis (Uji-t)

Setelah terpenuhi uji normalitas dan homogenitas, maka dilakukan uji-t. Uji ini digunakan untuk memastikan apakah hipotesis yang dilakukan dapat diterima atau tidak. Uji $t$ tersebut diperoleh berdasarkan tes akhir (posttest). 
TABEL 6 UJI BEDA RATA-RATA POSTTEST KELAS EKSPERIMEN DAN KELAS KONTROL

\begin{tabular}{|c|c|c|c|c|c|}
\hline No & Kelas & Nilai rata-rata & $t_{\text {thinumg }}$ & $\begin{array}{c}t_{t=b-B} \\
(a=0,05)\end{array}$ & Keputusan \\
\hline 1 & $\begin{array}{c}\text { Kelas } \\
\text { Eksperimen }\end{array}$ & 73,59 & \multirow[t]{2}{*}{4,04} & \multirow[t]{2}{*}{1,67} & \multirow[t]{2}{*}{$\mathrm{H}_{1}$ diterima } \\
\hline 2 & Kelas Kontrol & 60,73 & & & \\
\hline
\end{tabular}

Setelah dilakukan pengolahan data, dengan menggunakan uji-t diperoleh nilai $t_{\text {hitung }}>t_{\text {tabel }}$ atau $4,04>1,67$. Hal ini menunjukkan bahwa thitung berada diluar daerah penerimaan $\mathrm{H}_{0}$. Dengan demikian $\mathrm{H}_{1}$ diterima dan $\mathrm{H}_{0}$ di tolak.

\section{Pembahasan}

Hasil analisis data posttest untuk kelas eksperimen rerata skor yang diperoleh adalah 73,59 dengan standar deviasi 9,34, sedangkan kelas kontrol rerata skor yang diperoleh adalah 60,73 dengan standar deviasi 10,02.

Hasil analisis data di atas diperoleh hasil rerata skor yang menunjukkan bahwa hasil tes pemahaman konsep fisika dengan penggunaan model pembelajaran kooperatif tipe SFAE berbantuan komik edukatif lebih tinggi dibandingkan dengan hasil tes pemahaman konsep fisika siswa yang diajarkan dengan model pembelajaran konvensional.

Hal ini sesuai dengan uji $N$-gain yang menunjukkan hasil pemahaman konsep fisika siswa kelas X SMA Negeri 1 Palu meningkat dengan menggunakan model pembelajaran kooperatif tipe SFAE berbantuan komik edukatif. Hasil ini sesuai dengan penelitian sebelumnya [3], [4], [5] yang menyatakan terjadi peningkatan dengan menggunakan model pembelajaran kooperatif tipe SFAE dimana hasil perhitungan uji$t$ diperoleh $t_{\text {hitung }}$ berada diluar daerah penerimaan $\mathrm{H}_{0}$ sehingga terdapat pengaruh model pembelajaran kooperatif tipe SFAE berbantuan komik edukatif terhadap pemahaman konsep fisika siswa kelas X SMA Negeri 1 Palu.

Peningkatan hasil belajar siswa disebabkan karena penggunaan model dan media pembelajaran yang diterapkan. Model pembelajaran Student Facilitator and Expalaining (SFAE) mengajak siswa untuk dapat menjelaskan kepada siswa lain, siswa dapat mengeluarkan ide-ide yang ada dipikirannya dan dengan bantuan media pembelajaran yaitu komik edukatif dapat lebih memperjelas materi, menarik minat siswa untuk belajar sehingga siswa dapat dapat lebih memahami materi tersebut.

Penelitian ini membawa inovasi baru karena sebelumnya belum ada yang menggunakan komik edukatif dalam model pembelajaran ini. Siswa juga mendapat pengalaman baru dalam proses pembelajaran karena materi disajikan dalam bentuk komik edukatif. Sedangkan kekurangannya adalah model ini membutuhkan proses yang cukup lama, dan sebaiknya memperhitungkan waktu di setiap fase pembelajaran agar lebih efisien, karena waktu menjadi salah satu kendala dalam proses pembelajaran. Selain hal tersebut, adanya perbedaan tingkatan pembahasan materi yang diajarkan di kelas yang menjadi populasi sehingga membuat peneliti menggunakan sampel yang ada yang berbeda secara kemampuan dalam hal ini tingkat kecerdasan berdasarkan pertimbangan dari guru fisika di sekolah.

Instrumen yang mendukung berlangsungnya penelitian ini terdiri dari tes pemahaman konsep, rencana pelaksanaan pembelajaran, media, dan lembar kerja peserta didik. Dalam rencana pelaksanaan pembelajaran (RPP) tidak tercantum penilaian sikap dan psikomotorik karena dalam penelitian ini peneliti hanya mengkaji penilaian secara kognitif untuk mengukur tingkat pemahaman konsep pada siswa.

\section{KESIMPULAN DAN SARAN}

\section{Kesimpulan}

Berdasarkan hasil analisis data penelitian maka terjadi peningkatan pembelajaran dari 16,25 menjadi 29,34 di kelas eksperimen, begitupun di kelas kontrol. Sehingga dapat disimpulkan bahwa terdapat pengaruh model pembelajaran kooperatif tipe SFAE berbantuan komik edukatif terhadap pemahaman konsep fisika siswa kelas X SMA Negeri 1 Palu.

\section{Saran}

Peneliti berikutnya dalam menerapkan pembelajaran di kelas sebaiknya memahami kemampuan awal siswa. Hal ini dikarenakan siswa yang memiliki kemampuan awal tinggi akan berbeda cara penerimaan informasinya dengan siswa yang memiliki kemampuan awal sedang dan rendah. Dalam pelaksanaan pembelajaran dengan menggunakan SFAE yang masih tergolong baru dibutuhkan perhatian khusus dalam perencanaan waktu dengan baik sehingga dapat mengoptimalkan pembelajaran dan meminimalkan jumlah waktu yang terbuang. Hal yang belum ada dalam penelitian ini sebaiknya dapat diteliti oleh peneliti berikutnya, dengan menggunakan model pembelajaran yang lebih kompleks dan memperhatikan setiap aktivitas siswa di dalam kelas.

\section{DAFTAR PUSTAKA}

[1] Aziz. Penerapan Model Belajar Student Facilitator and Explaining pada Proses 
Pembelajaran Fisika Siswa Kelas X SMA Negeri 10 Purworejo. Skripsi. Purworejo, 2014.

[2] S. B. Djamarah. Psikologi Belajar. Jakarta: Rineka Cipta, 2002.

[3] Mawarsih. "Penerapan Model Pembelajaran Kooperatif Tipe Student Facilitator and Explaining untuk Meningkatkan Pemahaman Konsep Fisika pada Siswa Kelas X SMA Negeri 5 Palu". Jurnal Pendidikan Fisika Tadulako (JPFT), Vol. 4, No. 3, 2016.

[4] Nirsam. "Meningkatkan Hasil Belajar Fisika melalui Penerapan Model Pembelajaran
Kooperatif Tipe Student Facilitator and Explaining (SFAE) pada Siswa Kelas VIIID SMP Negeri 5 Palu". Jurnal Pendidikan Fisika Tadulako (JPFT), Vol. 1, No. 1, 2011.

[5] Putut, Hikmawati, Satutik. "Pengaruh Model Pembelajaran Kooperatif Tipe Student Facilitator and Explaining (SFAE) dengan Pendekatan Saintifik Terhadap Hasil Belajar Fisika". J. Pijar MIPA, Vol. XII, No. 1, 2017.

[6] Sudjana. "Metode Statistik". Bandung: CV. Tarsito, 2005. 